\title{
PROFIL BERPIKIR KREATIF DALAM MENYELESAIKAN SOAL CERITA MATEMATIKA
}

\author{
Dian Susanti \\ (Pendidikan Matematika, Fakultas Keguruan dan Ilmu Pendidikan, \\ Universitas PGRI Adi Buana Surabaya) \\ diansusanti2511@gmail.com
}

\begin{abstract}
This research will be based in the background by the problems often encountered by students that is completing a math problem, in particular the question of the story. Most students consider the intricate story is primarily a matter which could not be resolved in a practical way. Formulation of the problem in this research is "how the profile of the creative thinking of students of class VIII C 1 PGRI Surabaya in JUNIOR HIGH solve math story?". The purpose of this research is to know the profile of the creative thinking of students of class VIII C 1 PGRI Surabaya SMP in solving math story problem, especially in terms of his thinking ability. the thought process is a process that consists of the reception of information (from outside or in the students), management, storage, and callbacks that information from the student's memory. This means that in thinking someone is sure doing a process to find a conclusion or completion of something that thought. Thought process in this study are grouped into three conceptual thought process, that is the way of thinking of students in solving a problem using concepts that have been learned. Semikonseptual, that is the way of thinking of students in solying a problem using concepts that have been learned, but not complete. Computational, i.e. a way of thinking of students in solving a problem without using concepts that have been learned. In research done by using written tests, documentation, and interviews. The subject in this study consisted of 6 students consisting of two people of high ability students, two students are capable of being, and two low-capable students. The data obtained by means of the previous semester raport values obtained, test essay be reserved story sdah validated by two validator, and then in kroschek with the interview. The results showed that the thought process of a group of high-ability students tend to think conceptually, capabilities are likely to be in the process of thinking is semikonseptual, whereas the thought processes of a group of low ability students tend to be on Computational thinking processes.
\end{abstract}

Keywords: process of thinking, conceptual, computational, semikonseptual.

\section{PENDAHULUAN}

Pada hakekatnya pendidikan adalah suatu proses pembelajaran pola pikir yang bertujuan untuk meningkatkan kualitas diri. Keberhasilan penyelenggaraan pendidikan merupakan tolak ukur pendidikan. Salah satu pendidikan yang ada adalah pendidikan formal. Pendidikan formal mencakup beberapa aspek salah satunya adalah aspek pendidikan matematika.

Pendidikan matematika merupakan pendidikan dasar karena matematika adalah ilmu yang dapat dipakai dalam berbagai aspek keseharian, misalnya untuk bertransaksi jual beli dipasar dan perkapalan. Melalui proses pembelajaran matematika, diharapkan siswa dapat berfikir logis, kritis, teliti, sistematis dan efektif. Selain itu berpikir kreatif dalam pembelajaran matematika sangat dibutuhkan dalam memecahkan berbagai permasalahan matematika. Kreatifitas diperlukan untuk menemukan pemecahan masalah yang baru maupun menemukan hubungan dengan pemecahan masalah yang telah ada. Pada hakikatnya, manusia mempunyai potensi untuk menjadi kreatif. Kenyataan dilapangan menunjukkan kepada kita bahwa kemampuan siswa akan lebih baik jika kemampuan kreatif mereka juga turut dilibatkan baik secara formal maupun informal. Pada umumnya Siswa menghadapi permasalahan dalam penyelesaian soal matematika, khususnya soal cerita. Kebanyakan siswa menganggap soal cerita tersebut rumit terutama yang tidak dapat diselesaikan dengan cara praktis. Untuk mengatasi hal tersebut, salah satu alternatif yang dapat dilakukan adalah menggunakan metode mengajar yang sesuai dengan proses berpikir siswa. Cara berpikir siswa dalam menyelesaikan soal cerita dapat dilihat dalam pemecahan atau penyelesaian masalah yang dilakukan siswa dalam mengerjakan soal cerita. Adanya kelemahan siswa dalam 
menyelesaikan soal matematika dipengaruhi oleh tingkat kemampuan dan kreativitas matematika masing-masing siswa. Siswa yang memiliki kemampuan matematika rendah mungkin akan lebih banyak kelemahan dibanding siswa berkemampuan matematika tinggi. Sebagai. akibatnya, proses berpikir masing-masing siswa dalam menyelesaikan soal matematika juga berbeda bergantung pada tingkat kemampuan matematika yang dimiliki.

Kita semua menyadari akan pentingnya kreativitas sebagai motor bagi pendidikan. Pendidikan adalah penjemput hari depan bangsa agar lebih gemilang. Oleh karena itu, upaya upaya menumbuhkan semangat dalam berkreasi perlu digalakkan. Mengapa? sebab maju mundurnya pendidikan sedikit banyak ditentukan oleh berhasil tidaknya kita mengembangkan kreativitas.

Dari uraian diatas, penelitian ini ingin menjawab permasalaha, bagaimana profil berpikir kreatif siswa kelas VIII C SMP PGRI 1 Surabaya dalam menyelesaikan soal cerita matematika? yang hasilnya diharapkan dapat bermanfaat khususnya bagi guru matematika sebagai referensi dalam upaya mengembangkan pembelajaran matematika di sekolah. Dengan demikian, penelitian ini bertujuan untuk mengetahui bagaimana profil berpikir kreatif siswa dalam menyelesaikan soal cerita matematika.

\section{METODE PENELITIAN}

Penelitian ini bertujuan untuk mengetahui profil kemampuan berpikir kreatif siswa SMP PGRI 1 Surabaya. Pada penelitian ini siswa dikategorikan menjadi tiga yaitu siswa berkemampuan tinggi, siswa berkemampuan sedang, dan siswa berkemampuan rendah yang diperoleh dari hasil dokumentasi guru matematika di kelas VIII MP PGRI 1 Surabaya. Kemudian siswa tersebut melaksanakan pembelajaran matematika dengan menggunakan pembelajaran problem solving based, lalu diberi tes soal cerita mengenai pokok bahasan persamaan linier dua variabel, dan setelah itu hasil dari tes hasil belajar dicrosscheck dengan wawancara yang berisikan indikator proses berpikir siswa. Selanjutnya hasil dari pengumpulan data-data tersebut dianalisis secara mendalam berdasarkan langkah-langkah analisis data kualitatif.
Sumber data dalam penelitian adalah subyek dari mana data dapat diperoleh. Dalam penelitian ini sumber data meliputi siswa kelas VIII SMP PGRI 1 Surabaya sebanyak 6 siswa sebagai subjek penelitian yang telah dikelompokkan dari segi kemampuannya. Metode pengumpulan data pada penelitian ini menggunakan metode dokumentasi, metode tes, dan metode wawancara. Instrumen penelitian menggunakan lembar dokumentasi, lembar tes, dan lembar wawancara.

Data yang diperoleh dari hasil penelitian ini untuk selanjutnya dianalisis Langkah -langkah analisis dalam penelitian ini adalah:

1. Dari lembar dokumentasi yang berupa nilai rapot siswa kelas VII C pada semester sebelumnya maka dipilh 6 orang siswa yaitu 2 siswa berkemampuan tinggi, 2 siswa berkemampuan sedang dan 2 siswa dipilih 6 orang siswa yaitu 2 siswa berkemampuan tinggi, 2 siswa berkemampuan sedang dan 2 siswa berkemampuan rendah.

\section{Lembar Dokumentasi Nilai Rapot semester genap kelas VII C}

Siswa berkemampuan tinggi, sedang dan rendah

\begin{tabular}{|c|c|c|c|c|}
\hline No & Kod & Jenis & Nilai & Klasifika \\
$\mathbf{n}$ & $\begin{array}{c}\text { Sisw } \\
\text { kelami }\end{array}$ & Rap & si \\
ot & \\
\hline 20 & ILM & P & 90 & Tinggi \\
\hline 30 & PNT & P & 89 & Tinggi \\
\hline 02 & ARL & L & 83 & Sedang \\
\hline 11 & DAF & L & 82 & Sedang \\
\hline 03 & RH & L & 68 & Rendah \\
& M & & & \\
\hline 13 & DST & P & 67 & Rendah \\
\hline
\end{tabular}

Penentuan hasil tersebut diambil dari KKM sekolah

SMP PGRI 1 surabaya. Adapun KKM tersebut adalah sebagai berikut, Kategori kemampuan siswa:
a. Siswa berkemampuan tinggi: $85-100$
b. Siswa berkemampuan sedang: 70-84
c. Siswa berkemampuan rendah: $<70$ 
2. Mereduksi data dari soal yang di kerjakan oleh siswa sebanyak tiga soal cerita berbentuk uraian, kemudian data yang telah diperoleh dipaparkan dan di croschek dengan wawancara berisikan pertanyaan yang memenuhi indikator kemampuan berpikir dalam berbentuk tesk naratif.

3. Dari hasil dokumentasi tes, tes dan wawancara tersebut maka dilakukan penarikan kesimpulan sehingga dapat terdeskripsikan proses berpikir dari ketiga kemampuan iswa tersebut.

\section{HASIL DAN PEMBAHASAN}

Peneliti mengambil 6 subjek dari 43 siswa yang ada di kelas VIII C, ini dimaksudkan untuk mempermudah peneliti dalam melakukan penelitian. Pengambilan subjek juga di bantu oleh guru bidang studi matematika. Hal ini dilakukan karena guru bidang studi/lebih mengetahui karakter siswa sehingga lebih mudah untuk diteliti proses berpikirnya kemudian dari 6 subjek tersebut dibagi dalam tiga kategori kemampuan matematika siswa yaitu 2 orang siswa berkemampuan tinggi, 2 orang siswa berkemampuan sedang dan 2 orang siswa berkemampuan rendah. Untuk mengetahui nilai siswa dapat/dilihat pada tabel. Nilai siswa diurutkan dari nilai yang paling tinggi sampai yang paling rendah. Tes yang dilakukan berupa tes penyelesaian soal cerita. Sebelum soal digunakan, terlebih dahulu divalidasi oleh validator yang terdiri dari dosen matematika dan guru kelas bidang studi matematika. Validasi ini berkaitan dengan konstruksi, bahasa, dan isi/materi yang berkaitan dalam soal. Soal tes berupa soal dengan materi yang sudah diperoleh siswa sebelumnya.

Untuk mengetahui lebih lanjut tentang proses berpikir siswa dalam menyelesaikan permasalahan matematika, berikut diuraikan secara rinci proses berpikir dari keenam siswa. Aturan yang digunakan untuk mengetahui kecenderungan jenis proses berpikir siswa dalam menyelesaikan soal cerita yaitu: 1) siswa dikatakan memiliki proses berpikir konseptual apabila dalam menyelesaikan soal cerita memenuhi semua indikator proses berpikir konseptual, 2) siswa dikatakan memiliki proses berpikir semi konseptual apabila dalam menyelesaikan soal cerita memenuhi semua indikator proses berpikir semi konseptual, 3) siswa dikatakan memiliki proses berpikir komputasional apabila dalam menyelesaikan soal cerita memenuhi semua indikator proses berpikir komputasional. Hasil dari deskripsi proses berpikir ke enam siswa tersebut adalah sebagai berikut,

Hasil Proses Berpikir Siswa Kemampuan Tinggi, Sedang Dan Rendah

\begin{tabular}{|c|c|c|c|c|c|}
\hline $\begin{array}{c}\text { Subje } \\
\mathbf{k}\end{array}$ & $\begin{array}{c}\text { Tipe Proses } \\
\text { Berpikir }\end{array}$ & $\begin{array}{c}\text { Indikat } \\
\text { or }\end{array}$ & $\begin{array}{c}\text { Soa } \\
11\end{array}$ & $\begin{array}{c}\text { Soa } \\
12\end{array}$ & $\begin{array}{l}\text { Soa } \\
13\end{array}$ \\
\hline \multirow{16}{*}{$\begin{array}{c}1 . \\
\text { ILM }\end{array}$} & \multirow{5}{*}{ Konseptual } & A. 1 & $\sqrt{ }$ & $\sqrt{ }$ & $\sqrt{ }$ \\
\hline & & A.2 & $\sqrt{ }$ & $\sqrt{ }$ & $\sqrt{ }$ \\
\hline & & A.3 & $\sqrt{ }$ & $\sqrt{ }$ & $\sqrt{ }$ \\
\hline & & A. 4 & $\sqrt{ }$ & $\sqrt{ }$ & $\sqrt{ }$ \\
\hline & & A.5 & $\sqrt{ }$ & $\sqrt{ }$ & $\sqrt{ }$ \\
\hline & \multirow{5}{*}{$\begin{array}{c}\text { Semi } \\
\text { Konseptual }\end{array}$} & B. 1 & & & \\
\hline & & B.2 & & & \\
\hline & & B.3 & & & \\
\hline & & B.4 & & & \\
\hline & & B.5 & & & \\
\hline & \multirow{5}{*}{ Komputasio } & C. 1 & & & \\
\hline & & C. 2 & & & \\
\hline & & C. 3 & & & \\
\hline & & C. 4 & & & \\
\hline & & C.5 & & & \\
\hline & \multirow{5}{*}{ Konseptual } & A. 1 & $\sqrt{ }$ & $\sqrt{ }$ & $\sqrt{ }$ \\
\hline \multirow{13}{*}{ PNT } & & A. 2 & $\sqrt{ }$ & $\sqrt{ }$ & $\sqrt{ }$ \\
\hline & & A.3 & $\sqrt{ }$ & $\sqrt{ }$ & $\sqrt{ }$ \\
\hline & & A.4 & $\sqrt{ }$ & $\sqrt{ }$ & $\sqrt{ }$ \\
\hline & & A. 5 & $\sqrt{ }$ & $\sqrt{ }$ & $\sqrt{ }$ \\
\hline & \multirow{5}{*}{$\begin{array}{c}\text { Semi } \\
\text { Konseptual }\end{array}$} & B.1 & & & \\
\hline & & B. 2 & & & \\
\hline & & B. 3 & & & \\
\hline & & B.4 & & & \\
\hline & & B.5 & & & \\
\hline & \multirow{4}{*}{$\begin{array}{c}\text { Komputasio } \\
\text { nal }\end{array}$} & C.1 & & & \\
\hline & & C. 2 & & & \\
\hline & & C. 3 & & & \\
\hline & & C. 4 & & & \\
\hline
\end{tabular}




\begin{tabular}{|c|c|c|c|c|c|}
\hline $\begin{array}{c}\text { Subje } \\
\mathbf{k}\end{array}$ & $\begin{array}{c}\text { Tipe Proses } \\
\text { Berpikir }\end{array}$ & $\begin{array}{c}\text { Indikat } \\
\text { or }\end{array}$ & $\begin{array}{c}\text { Soa } \\
11\end{array}$ & $\begin{array}{c}\text { Soa } \\
12\end{array}$ & $\begin{array}{r}\text { Soa } \\
13\end{array}$ \\
\hline & & C.5 & & & \\
\hline \multirow{15}{*}{$\begin{array}{c}3 . \\
\text { ARL }\end{array}$} & \multirow{5}{*}{ Konseptual } & A.1 & & & \\
\hline & & A. 2 & & & \\
\hline & & A.3 & & & \\
\hline & & A.4 & & & \\
\hline & & A.5 & $\sqrt{ }$ & $\sqrt{ }$ & \\
\hline & \multirow{5}{*}{$\begin{array}{c}\text { Semi } \\
\text { Konseptual }\end{array}$} & B.1 & $\sqrt{ }$ & $\sqrt{ }$ & $\sqrt{ }$ \\
\hline & & B. 2 & $\sqrt{ }$ & $\sqrt{ }$ & $\sqrt{ }$ \\
\hline & & B.3 & $\sqrt{ }$ & $\sqrt{ }$ & \\
\hline & & B.4 & $\sqrt{ }$ & $\sqrt{ }$ & \\
\hline & & B.5 & & & \\
\hline & \multirow{5}{*}{$\begin{array}{c}\text { Komputasio } \\
\text { nal }\end{array}$} & C. 1 & & & \\
\hline & & C. 2 & & & \\
\hline & & C. 3 & & & $\sqrt{ }$ \\
\hline & & C. 4 & & & $\sqrt{ }$ \\
\hline & & C.5 & & & $\sqrt{ }$ \\
\hline \multirow{15}{*}{$\begin{array}{r}4 . \\
\text { DAF }\end{array}$} & \multirow{5}{*}{ Konseptual } & A.1 & & $\sqrt{ }$ & \\
\hline & & A. 2 & & & \\
\hline & & A.3 & & & \\
\hline & & A.4 & & & \\
\hline & & A.5 & $\sqrt{ }$ & & \\
\hline & \multirow{5}{*}{$\begin{array}{c}\text { Semi } \\
\text { Konseptual }\end{array}$} & B. 1 & $\sqrt{ }$ & & \\
\hline & & B.2 & $\sqrt{ }$ & $\sqrt{ }$ & \\
\hline & & B.3 & $\sqrt{ }$ & $\sqrt{ }$ & $\sqrt{ }$ \\
\hline & & B. 4 & $\sqrt{ }$ & $\sqrt{ }$ & $\sqrt{ }$ \\
\hline & & B.5 & & 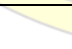 & \\
\hline & \multirow{5}{*}{$\begin{array}{c}\text { Komputasio } \\
\text { nal }\end{array}$} & C.1 & & & \\
\hline & & C. 2 & & & \\
\hline & & C. 3 & & & \\
\hline & & C. 4 & & & \\
\hline & & C.5 & & & \\
\hline \multirow{6}{*}{$\begin{array}{c}5 . \mathrm{RH} \\
\mathrm{M}\end{array}$} & \multirow{5}{*}{ Konseptual } & A.1 & & & \\
\hline & & A. 2 & & & \\
\hline & & A.3 & & & \\
\hline & & A. 4 & & & \\
\hline & & A.5 & & & \\
\hline & & B.1 & & & \\
\hline
\end{tabular}

\begin{tabular}{|c|c|c|c|c|c|}
\hline $\begin{array}{c}\text { Subje } \\
\mathbf{k}\end{array}$ & $\begin{array}{c}\text { Tipe Proses } \\
\text { Berpikir }\end{array}$ & $\begin{array}{c}\text { Indikat } \\
\text { or }\end{array}$ & $\begin{array}{l}\text { Soa } \\
11\end{array}$ & $\begin{array}{c}\text { Soa } \\
12\end{array}$ & $\begin{array}{c}\text { Soa } \\
13\end{array}$ \\
\hline & \multirow{4}{*}{$\begin{array}{c}\text { Semi } \\
\text { Konseptual }\end{array}$} & B. 2 & & & \\
\hline & & B.3 & & & \\
\hline & & B.4 & & & \\
\hline & & B.5 & & & \\
\hline & \multirow{5}{*}{$\begin{array}{c}\text { Komputasio } \\
\text { nal }\end{array}$} & C.1 & $\sqrt{ }$ & $\sqrt{ }$ & $\sqrt{ }$ \\
\hline & & C. 2 & $\sqrt{ }$ & $\sqrt{ }$ & $\sqrt{ }$ \\
\hline & & C.3 & $\sqrt{ }$ & $\sqrt{ }$ & $\sqrt{ }$ \\
\hline & & C. 4 & $\sqrt{ }$ & $\sqrt{ }$ & $\sqrt{ }$ \\
\hline & & C.5 & $\sqrt{ }$ & $\sqrt{ }$ & $\sqrt{ }$ \\
\hline \multirow{15}{*}{$\begin{array}{l}\text { 6.DS } \\
\mathrm{T}\end{array}$} & \multirow{5}{*}{ Konseptual } & A. 1 & & & \\
\hline & & A. 2 & & & \\
\hline & & A. 3 & & & \\
\hline & & A. 4 & & & \\
\hline & & A.5 & & & \\
\hline & \multirow{5}{*}{$\begin{array}{c}\text { Semi } \\
\text { Konseptual }\end{array}$} & B.1 & & & \\
\hline & & B. 2 & & & \\
\hline & & B.3 & & & \\
\hline & & B.4 & & & \\
\hline & & B.5 & & & \\
\hline & \multirow{5}{*}{$\begin{array}{c}\text { Komputasio } \\
\text { nal }\end{array}$} & C.1 & $\sqrt{ }$ & $\sqrt{ }$ & $\sqrt{ }$ \\
\hline & & C. 2 & $\sqrt{ }$ & $\sqrt{ }$ & $\sqrt{ }$ \\
\hline & & C. 3 & $\sqrt{ }$ & $\sqrt{ }$ & $\sqrt{ }$ \\
\hline & & C. 4 & $\sqrt{ }$ & $\sqrt{ }$ & $\sqrt{ }$ \\
\hline & & C.5 & $\sqrt{ }$ & $\sqrt{ }$ & $\sqrt{ }$ \\
\hline
\end{tabular}

Keterangan : dikatakan memenuhi proses berpikir apabila kelima indikator memenuhi satu proses berpikir yang sama.

Dari tabel diatas maka dikatakan bahwa siswa berkemampuan tinggi memenuhi kelima indikator konseptual, siswa berkemampuan rendah tidak selalu memenuhi kelima indikator yang sama tetapi lebih cenderung pada indikator semikonseptual, dan siswa berkemampuan rendah memenuhi kelima indikator yang sama yaitu indikator komputasional. 


\section{PENUTUP}

\section{Simpulan}

Berdasarkan hasil penelitian yang dilakukan serta berdasarkan analisis data yang ada, maka diperoleh kesimpulan sebagai berikut.

1. Proses berpikir siswa berkemampuan tinggi dalam menyelesaikan soal cerita Persamaan Linier Dua Variabel yaitu:

a. Mampu menyatakan yang diketahui dalam soal dengan bahasa sendiri.

b. Mampu mengungkapkan dengan kalimat sendiri apa yang ditanya dalam soal.

c. Dalam menjawab cenderung menggunakan konsep yang sudah dipelajari.

d. Mampu menjelaskan langkah yang ditempuh sesuai dengan konsep yang telah dipelajari.

e. Serta mampu memperbaiki jawaban.

2. Proses berpikir siswa berkemampuan sedang dalam menyelesaikan soal cerita Persamaan Linier Dua Variabel yaitu :

a. Kurang mampu menyatakan yang diketahui dalam soal dengan menggunakan bahasa sendiri.

b. Kurang mampu mengungkapkan dengan kalimat sendiri apa yang ditanya dalam soal.

c. Dalam menjawab soal cenderung menggunakan apa yang sudah dipelajari walaupun tidak lengkap.

d. Kurang mampu menyatakan langkah-langkah yang ditempuh dalam menyelesaikan soal menggunakan konsep yang pernah dipelajari.

e. Serta kurang mampu memperbaiki kekeliruan jawaban.

3. Sedangkan proses berpikir siswa berkemampuan rendah dalam menyelesaikan soal cerita Persamaan Linier Dua Variabel yaitu :

a. Tidak mampu menyatakan yang diketahui dalam soal dengan menggunakan bahasa sendiri.

b. Tidak mampu mengungkapkan dengan kalimat sendiri apa yang ditanya pada soal.

c. Dalam menjawab cenderung lepas dari konsep yang telah dipelajari. d. Tidak mampu menjelaskan langkah-langkah yang ditempuh sesuai dengan konsep yang telah dipelajari.

e. Serta tidak mampu memperbaiki kekeliruan jawaban.

Berdasarkan hal tersebut, maka dapat disimpulkan bahwa jenis proses berpikir siswa berkemampuan tinggi adalah konseptual, jenis proses berpikir siswa berkemampuan sedang yaitu semikonseptual, dan jenis proses berpikir siswa berkemampuan rendah yaitu komputasional.

\section{Saran}

Berdasarkan penelitian yang telah dilaksanakan, maka peneliti dapat memberikan saran bagi pembaca, peneliti yang akan melakukan penelitian yang sama adalah sebagai berikut,

1. Bagi Sekolah

Agar dapat mencapai tujuan pendidikan yang diharapkan, hendaknya kepada sekolah dapat membuat kebijakan-kebijakan yang dapat meningkatkan dan mengembangkan mutu pendidikan.

\section{Bagi Guru}

Diharapkan lebih mengembangkan serta menciptakan metode pembelajaran yang dapat meningkatkan kreativitas siswa dalam pendidikan.

3. Bagi Siswa

Diharapkan siswa dapat lebih meningkatkan kemampuan matematikanya dalam pembelajaran sehingga dapat meningkatkan pemahaman serta memperoleh hasil belajar yang maksimal.

4. Bagi Penelitian yang akan datang

Penelitian ini dapat memberikan reverensi mengenai proses berpikir siswa dalam menyelesaikan soal cerita matematika. Bagi peneliti selanjutnya diharapkan lebih bisa mengembangkan dan mendeskripsikan baik lagi tema yang serupa dengan dengan penelitian ini.

\section{DAFTAR PUSTAKA}

Arikunto Suharsimi. 2013. Dasar-dasar Evaluasi Pendidikan. Jakarta : Bumi aksara. 
Eka, Kharisma. (2008). Proses berpikir siswa dalam menyelesaikan soal cerita di SMU Kelas X. Universitas negeri surabaya. Skripsi tidak dipublikasikan Http://www.suchaini.wordpress.com/2008/12/15/teori -berpikir-kreatif pendidikan/ R. Soedjadi, Kiat-Kiat Pendidikan Matematika di Indonesia, (Jakarta: DirektoratJenderalPendidikan Tinggi, Departemen Pendidikan Nasional,2000). ( diakses pukul 23.55 WIB, 24-12-2015)

Haylock, Derek. 1997. "Recognising Mathematical Creativity in Schoolchildren". http://www.fiz.karlsruhe.de.fiz/publication/zdm ZDM Volum 29 (juni 1997) No.3 Electronic Edition ISSN 1615-679X (diakses pukul 00.15 WIB, 27-12-2015). Ismaimuza, Daza. (2010). Kemampuan Berpikir Kritis dan Matematis Siswa SMP Melalui Pembelajaran Berbasis Masalah dengan Strategi Konflik Kognitif. Disertasi pada SPs, tidak dipublikasikan. Bandung: UPI. (Diakses tanggal 20 juni 2015 pukul 23.35)

Kreano. Analisis Proses dan Kemampuan Berpikir Kreatif Siswa dalam Matematika Melalui Tugas Open Ended. Vol. 3. No. 2 Desember 2012. ISSN : 2086 2334.

Lexy J. Moleong, 2011. Metodologi penelitian kualitatif.Bandung :P.T Remaja Rosdakarya
Mahmudi, A. 2010. "Mengukur Kemampuan Berpikir Kreatif Matematis". Makalah. Konferensi Nasional Matematika XV UNIMA 30 Juni - 3 Juli 2010. (diakses pukul 23:50 WIB, 09-12-2015).

Moleong, L. (2009). Metode Penelitian Kualitatif. Edisi Revisi. Bandung: PT. Remaja Rosdakarya.

Munandar, Utami. (1999). Pengembangan Kreativitas Anak Berbakat. Hal 58- 59. PT Rineka Cipta. Jakarta: (1999)

Sudarma, Momon. 2013. Mengembangkan Kemampuan Berpikir Kreatif. Jakarta : Penerbit PT Rajagrafindo Perkasa.

Sugiyono. 2014. Metode Penelitian Kuantitatif Kualitatif dan $R \& D$. Bandung :Alfabeta.

Susanto, Hadi. 2013. Pentingnya Metode Polya dan Bentuk Soal Cerita dalam Pembelajaran Matematika.

Tambunan, H. (1999). Kemampuan Siswa Menyelesaikan Soal Cerita Pokok Bahasan Trigonometri Dengan Strategi Heuristik. Tesis, tidak dipublikasikan. Surabaya: UNESA

Zuhri D. Proses Berpikir Siswa Kelas II SMPN Pekanbaru dalam Menyelesaikan Soal-Soal Perbandingan Berbalik Nilai. Tesis Sarjana Pendidikan, ( Surabaya: Perpustakaan Pascasarjana UNESA, 2012) 